\section{Is subjective social status a summary of life-course socioeconomic position?}

\section{O status social subjetivo é uma medida sumária da posição socioeconômica ao longo da vida?}

\section{¿Es el estatus social subjetivo una medida sumaria de la posición socioeconómico a lo largo de la vida?}

Wasney de Almeida Ferreira 1

Lidyane Camelo 1

Maria Carmen Viana 2

Luana Giatti 1

Sandhi Maria Barreto 1

\begin{abstract}
Very little is known about the association between objective indicators of socioeconomic position in childhood and adolescence and low subjective social status in adult life, after adjusting for adult socioeconomic position. We used baseline data (2008-2010) from the Brazilian Longitudinal Study of Adult Health (ELSA-Brasil), a multicenter cohort study of 15,105 civil servants from six Brazilian states. Subjective social status was measured using the The MacArthur Scale of Subjective Social Status, which represents social hierarchy in the form of a 10-rung ladder with the top rung representing the highest subjective social status. Participants who chose the bottom four rungs in the ladder were assigned to the low subjective social status category. The following socioeconomic position indicators were investigated: childhood (maternal education), adolescence (occupational social class of the household head; participant's occupational social class of first job; nature of occupation of household head; participant's nature of occupation of first job), and adulthood (participant's occupational social class, nature of occupation and education). The associations between low subjective social status and socioeconomic position were determined using multiple logistic regression, after adjusting for sociodemographic factors and socioeconomic position indicators from other stages of life. After adjustments, low socioeconomic position in childhood, adolescence and adulthood remained significantly associated with low subjective social status in adulthood with dose-response gradients. The magnitude of these associations was stronger for intra-individual than for intergenerational socioeconomic positions. Results suggest that subjective social status in adulthood is the result of a complex developmental process of acquiring socioeconomic self-perception, which is intrinsic to subjective social status and includes current and past, individual and family household experiences.
\end{abstract}

\author{
Correspondence \\ S. M. Barreto \\ Faculdade de Medicina, Universidade Federal de Minas Gerais. \\ Av. Alfredo Balena 190, Belo Horizonte, MG 30130-100, Brasil. \\ sandhi.barreto@gmail.com \\ 1 Faculdade de Medicina, Universidade Federal de Minas \\ Gerais, Belo Horizonte, Brasil. \\ 2 Departamento de Medicina Social, Universidade Federal do \\ Espirito Santo, Vitoria, Brasil.
}




\section{Introduction}

There is substantial evidence that individuals with low socioeconomic status have poorer health conditions compared to those with higher socioeconomic positions. This association has been observed in studies that measured social status using objective indicators such as income, education, and occupation, as well as in studies based on subjective indicators of socioeconomic status 1,2,3,4.

Objective social status (OSS) refers to the prestige attributed to a socioeconomic position, which provides access to certain services, resources, and knowledge 5 . In addition to prestige, status encompasses power and honor, both attributes that also enhance contacts, control, and sociopolitical influence 6 . Thus, health inequalities are believed to largely be a reflection of material inequalities that result in less access to goods and services among underprivileged individuals, which include access to adequate nutrition, sanitation, education and health care.

Subjective social status (SSS) is a measure of an individual's perception of his/her socioeconomic position (SEP) in relation to others (in his/her society/community), and is usually based on objective indicators such as income, education, and occupation ${ }^{7}$. Subjective class identification is a feeling of a specific degree of belong to something, to feel part of a "class culture", to identify (or contrast) himself with (from) others, to share values and habits 8 . Thus, health inequalities may also reflect subjective socioeconomic inequalities, expressed by the greater vulnerability to the health risks of individuals who consider themselves worse off or at a socioeconomic disadvantage when compared to their counterparts.

Several studies have used the The MacArthur Scale of Subjective Social Status (MacArthur Scale) to measure SSS in society at large 9,10,11. In this scale, participants place themselves on a drawing of a 10-rung ladder according to where they feel they stand within the social hierarchy. Thus, the rungs in the ladder metaphorically represent the self-perception of social class 12 . Studies using the MacArthur Scale have found that health status is inversely related to perceived position in the social hierarchy and the association is consistent when self-rated health is used to assess health status, even after adjusting for objective socioeconomic indicators 11,13,14.

According to Singh-Manoux et al. 15, objective social status is more likely to capture social status at a specific point in time, whereas SSS reflects not only current status, but also the past and perceived future prospects. The issue of socioeconomic self-perception is intrinsic to SSS and related to Developmental Psychology, which recognizes that the notions of self, space, time, causality, morality, alterity, social identity, and even social perception are not innate or learned, but developed throughout life 16. Thus, one can assume that the SSS of an adult and his/her self-perceived position in the social hierarchy might also be the result of a complex developmental process, which includes the influence of socioeconomic conditions in childhood and adolescence.

There is strong evidence linking adulthood SEP to early life SEP (both, of individuals and of their parents) ${ }^{17}$. The creators of the SSS ladder states that the position of oneself on the SSS ladder picks up something meaningful for health, but it is not clear what this position reflects. They asked whether SSS ratings are simply reflections of other variables with which they are confounded. However, Singh-Manoux et al. 15 showed that ladder rankings predicted global health three years later, controlling for baseline global health status and SEP, supporting that SSS ratings capture a hidden dimension of the relation of social stressors and health that is not exhibited by objective SEP. Results from the English Longitudinal Study of Aging support that SSS is an important correlation of health in old age, possibly because of its ability to epitomize life-time achievement and socioeconomic status 2 .

In as much as the above associations support the view that SSS in adulthood would be associated with SEP in early life, there remains a need to demonstrate such associations, as only one study has addressed this question. However, this previous study examined only the association of SSS with parental SEP, thus missing the question of the association of SSS with intra-generational indicators of early SEP 15. Moreover, other studies showed that different components of SEP appear to have more influence on an individual's SSS: while in the Whitehall II cohort the occupational grade was more influential, in the Cardia cohort income appeared to be stronger 18, suggesting that SSS may grab distinct social aspects in different populations. Furthermore, the fact that SSS remains associated with health outcomes after adjusting for current SEP requires a deeper understanding of the relationship 
between SSS and early SEP. Knowing that adulthood SSS reflects a socioeconomic trajectory across the life-course, beyond other things not examined in this study, may help to explain why it remains associated with health outcomes after considering the individual SEP.

Thus, this study aimed to investigate whether objective indicators of SEP in childhood and adolescence are associated with SSS in adulthood, after adjusting for SEP in adulthood. Our hypothesis is that exposure to adverse SEP in early life is associated with greater chances of having a low SSS in adulthood, independent of the current SEP.

\section{Methods}

\section{Study population}

This study used baseline data from the Brazilian Longitudinal Study of Adult Health (ELSA-Brasil, 2008-2010), a multicenter cohort study of 15,105 civil servants (comprising 12,096 current workers and 3,009 retired workers) of both genders, between 35 and 74 years of age, and enrolled in five universities and one research institute across six Brazilian states (São Paulo, Minas Gerais, Rio Grande do Sul, Bahia, Espírito Santo, and Rio de Janeiro). The ELSA-Brasil cohort comprises of voluntary participants and efforts were made to recruit similar amounts of men and women, as well as predefined proportions of age groups and occupational categories. More details about the study design, selection criteria and recruitment methods can be found elsewhere 19,20. The baseline examination included a face-to-face interview and clinical, laboratory and anthropometric examinations. The ELSA-Brasil protocol was approved at each of the six study centers by the local Institutional Review Board addressing research using human participants. Written, informed consent was provided by all participants.

\section{Study variables}

\section{- Subjective social status}

SSS was measured using the MacArthur Scale for the society, which represents the social hierarchy in the form of a 10-rung ladder with the top rung representing the highest SSS. In a study that assessed the reliability of the MacArthur Scale in a subsample of ELSA-Brasil participants, Giatti et al. 9 found an intraclass correlation coefficient of 0.67 , indicating a substantial test-retest agreement. A standard statement was presented to participants by trained and certified ELSA-Brasil interviewers and they were asked to choose the rung that best represented their relative position in society at large 9. Participants who chose the bottom four rungs (1-4) were classified as being in the low SSS category and were compared to the remaining participants. We decided to use a cutoff to simplify the analysis and to facilitate the interpretation of results. The distribution of SSS scores is asymmetric, with a right deviation. Other studies have also used SSS as a categorical variable, although no cutoff point has ever been established 1,14,15.

\section{- Life-course SEP indicators}

\section{(a) Socio-occupational indicators}

Two socio-occupational indicators were used for the current and adolescence SEP: the occupational social class of the household head at the time the participant started working and the participant's occupational social class of first job. On average, ELSA's participants started working at the age of 17 years. To determine the occupational social class of the household head at the time the participant started working, participants were asked: "What was the main occupation or activity of the household head or main provider of household income at the time you started working?" To obtain information on the participant's occupation in adolescence, participants were asked: "What was your occupation or activity in your first job?". The participant's current occupational social class was used as an SEP 
indicator in adulthood, and to ascertain it, participants were asked "Please, describe the main tasks performed by you in your current work day". Occupational social class is a summary measure that includes three variables: occupation, observed income and expected income based on the required education level for that occupation (average market value). Participants' current occupation, in adolescence and that of the household head were assigned to the following occupational social classes: upper-high, upper-low, middle-high, middle-middle, middle-low, lower-high, and lower-low. Only the middle class have three sub-categories. For this analysis, the upper-high and upper-low classes were grouped into the upper class.

\section{(b) Nature of occupation indicators}

The nature of occupation of household head at the time the participant started working and the participant's nature of occupation in first job were used as SEP indicators in adolescence. The participant's current nature of occupation was used as an SEP indicator in adulthood. Information on these variables was obtained from the same three questions asked in the section above, with the first two occupational category variables relative to the participant's adolescence and the third to his/her adulthood. Participants and household heads were assigned to the following occupational categories: non-routine non-manual, routine non-manual, non-routine manual, and routine manual jobs.

\section{(c) Education indicators}

Maternal education attainment and the participant's current education level were used as SEP indicators in childhood and adulthood, respectively. To determine maternal education, participants were asked: "What is your mother's level of education?"; maternal education was categorized into tertiary education, secondary education, primary education, incomplete primary education, and no education. To determine the participant's current education level, participants were asked: "What is your level of education?"; participants were assigned to the following levels: tertiary education, secondary education, primary education, and incomplete primary education. Maternal education and participant education were categorized differently because of the large difference in education levels between the two generation groups.

\section{- Other sociodemographic variables}

Age (age groups: 35-44, 45-54, 55-64, and 65-74 years), gender (male; female), active/retired status, and self-reported race (White, Brown, Black, Asian descent, and Brazilian indigenous) were selected as potential confounding factors.

\section{Data analysis}

First, the overall prevalence of low SSS was determined and we used the chi-square test for trend to verify any potential trend in the prevalence of low SSS according to the level of the independent variables. The associations between life-course SEP indicators and low SSS were investigated using multiple logistic regression analysis. The analyses were carried out for the three sets of SEP indicators shown in Figure 1: (1) SEP based on individuals and the head of household's occupational social class; (2) SEP defined by individuals and the head of household's occupational nature; and (3) SEP based on the participants and their mothers educational levels. Each analysis was carried out separately, but using the same strategy. First, the crude odds ratio (OR) values for each SEP indicator were calculated (Model 0), following adjustment for gender, age, active/retired status, and self-perceived race (Model 1). Next, the models were further adjusted for the other SEP indicators of the same set (Models 2 and 3). The strengths of the associations were estimated by the OR and respective $95 \%$ confidence intervals $(95 \% \mathrm{CI})$. Associations were considered significant at $\mathrm{p}<0.05$. 
Figure 1

Analytical groups of socioeconomic positions (SEP) indicators used in the investigation of the associations between low objective SEP and low subjective social status (SSS) in society.

\begin{tabular}{|ll|}
\hline Analytical group & Life stage \\
Group 1: based on occupational social class & \\
Occupational social class of household head & Adolescence \\
Occupational social class of first job & Adolescence \\
Current occupational social class & Adulthood \\
Group 2: based on occupational nature & \\
Nature of occupation of household head & Adolescence \\
Nature of occupation in first job & Adolescence \\
Nature of current occupation & Adulthood \\
Group 3: based on education & \\
Maternal education & Childhood \\
Participant education & Adulthood \\
\hline
\end{tabular}

\section{Results}

Of the 15.105 participants, $54.4 \%$ were women, the mean age was 52.1 years (95\%CI: $45-58), 80.3 \%$ were occupationally active, $51.6 \%$ were white, and $10.7 \%$ placed themselves in the low SSS category.

The prevalence of low SSS was inversely related to the occupational social class of the household head and the participants' occupational social class of their first and current jobs (Table 1). Similarly, in general the prevalence of low SSS according to nature of occupation gradually increased among those with more skilled jobs to those with less skilled jobs. Lastly, the prevalence of low SSS was inversely related to maternal education level and to the participant's current education level. All the associations above were statistically significant $(\mathrm{p}<0.05$, Table 1$)$.

Table 2 shows the univariable and multivariable analysis for occupational social class indicators. In the crude model, using the upper class as a reference, low occupational social class was associated with higher odds for low SSS in all life stages, with a dose-response gradient in all associations. By adjusting for sociodemographic variables and the occupational social class in each subsequent life stage the associations were attenuated, but remained statistically significant. The associations between low SSS and life-course occupational social class also showed a dose-response gradient across life stages and were stronger for the current social class (Model 3).

The univariable and multivariable analysis for the nature of occupation indicators are shown in Table 3. In the crude model, using non-routine non-manual jobs as a reference, routine manual jobs were associated with higher odds for low SSS in all life stages. In the adjusted model, low SSS remained independently associated with the three variables of the model (Model 3).

The univariable and multivariable analysis for education indicators are shown in Table 4. In the crude model, using completed university education as reference, low maternal education and low participant education were associated with higher odds for low SSS. In the adjusted model, the associations between low SSS and education indicated a dose-response gradient across life stages, although the OR for mothers with complete primary and secondary education were not statistically significant (Model 2). 
Table 1

Absolute and relative frequencies of low subjective social status (SSS) in society across life-course socioeconomic position (SEP) indicators. ELSA-Brasil, $2008-2010(N=15,105)$

\begin{tabular}{|c|c|c|c|c|c|}
\hline \multirow[t]{2}{*}{ SEP indicators across life-course } & \multicolumn{2}{|c|}{ Population } & \multicolumn{2}{|c|}{ Low SSS } & \multirow[t]{2}{*}{ p-value * } \\
\hline & $\mathbf{n}$ & $\%$ & $\mathbf{n}$ & $\%$ & \\
\hline \multicolumn{6}{|l|}{ Childhood } \\
\hline Maternal education level & & & & & $<0.001$ \\
\hline Tertiary & 955 & 6.3 & 28 & 2.9 & \\
\hline Secondary & 2,558 & 16.9 & 112 & 4.4 & \\
\hline Primary & 2,869 & 19.0 & 212 & 7.4 & \\
\hline Incomplete primary & 6,276 & 41.5 & 735 & 11.7 & \\
\hline No education & 2,081 & 13.8 & 446 & 21.5 & \\
\hline \multicolumn{6}{|l|}{ Adolescence } \\
\hline Occupational social class of the household head & & & & & $<0.001$ \\
\hline Upper & 3,137 & 20.8 & 118 & 3.8 & \\
\hline Middle-high & 1,406 & 9.3 & 72 & 5.1 & \\
\hline Middle-middle & 1,085 & 7.2 & 89 & 8.2 & \\
\hline Middle-low & 1,585 & 10.5 & 173 & 10.9 & \\
\hline Lower-high & 4,404 & 29.2 & 553 & 12.6 & \\
\hline Lower-low & 2,750 & 18.2 & 543 & 19.8 & \\
\hline Participant occupational social class of first job & & & & & $<0.001$ \\
\hline Upper & 847 & 5.6 & 14 & 1.7 & \\
\hline Middle-high & 1,618 & 10.7 & 68 & 4.2 & \\
\hline Middle-middle & 466 & 3.1 & 25 & 5.4 & \\
\hline Middle-low & 2,178 & 14.4 & 176 & 8.1 & \\
\hline Lower-high & 5,639 & 37.3 & 705 & 12.5 & \\
\hline Lower-low & 2,047 & 13.6 & 514 & 25.2 & \\
\hline Nature of occupation of the household head & & & & & $<0.001$ \\
\hline Non-routine non-manual & 4,538 & 30.0 & 195 & 4.3 & \\
\hline Routine non-manual & 4,534 & 30.0 & 594 & 13.1 & \\
\hline Non-routine manual & 2,021 & 13.4 & 232 & 11.5 & \\
\hline Routine manual & 3,274 & 21.7 & 527 & 16.1 & \\
\hline Nature of occupation in first job of the participant & & & & & $<0.001$ \\
\hline Non-routine non-manual & 2,450 & 16.2 & 71 & 2.9 & \\
\hline Routine non-manual & 6,615 & 43.8 & 706 & 10.7 & \\
\hline Non-routine manual & 1,373 & 9.1 & 247 & 18.1 & \\
\hline Routine manual & 2,357 & 15.6 & 478 & 20.3 & \\
\hline \multicolumn{6}{|l|}{ Adulthood } \\
\hline Participant current occupational social class & & & & & $<0.001$ \\
\hline Upper & 4,955 & 32.8 & 118 & 2.4 & \\
\hline Middle-high & 707 & 4.7 & 35 & 5.0 & \\
\hline Middle-middle & 2,806 & 18.6 & 269 & 9.6 & \\
\hline Middle-low & 2,717 & 18.0 & 365 & 13.4 & \\
\hline Lower-high & 1,384 & 9.2 & 197 & 14.3 & \\
\hline Lower-low & 2,291 & 15.2 & 625 & 27.4 & \\
\hline Participant current nature of occupation & & & & & $<0.001$ \\
\hline Non-routine non-manual & 7,893 & 52.3 & 365 & 4.6 & \\
\hline Routine non-manual & 4,278 & 28.3 & 522 & 12.2 & \\
\hline Non-routine manual & 200 & 1.3 & 39 & 19.6 & \\
\hline Routine manual & 2,489 & 16.5 & 683 & 27.5 & \\
\hline Participant education level & & & & & $<0.001$ \\
\hline Tertiary & 7,950 & 52.6 & 267 & 3.4 & \\
\hline Secondary & 5,233 & 34.6 & 809 & 15.5 & \\
\hline Primary & 1,028 & 6.8 & 232 & 22.6 & \\
\hline Incomplete primary & 894 & 5.9 & 310 & 34.9 & \\
\hline
\end{tabular}

* Chi-square for trend of low SSS. 
Table 2

Association between low subjective social status (SSS) in society and occupational social class of participant and household head at the time the participant started working. ELSA-Brasil, 2008-2010 ( $\mathrm{N}=15,105)$.

\begin{tabular}{|c|c|c|c|c|}
\hline Variable & $\begin{array}{c}\text { Crude } \\
\text { OR }(95 \% \mathrm{CI})\end{array}$ & $\begin{array}{c}\text { Model } 1 \\
\text { OR }(95 \% \mathrm{Cl})\end{array}$ & $\begin{array}{c}\text { Model } 2 \\
\text { OR }(95 \% \mathrm{CI})\end{array}$ & $\begin{array}{c}\text { Model } 3 \\
\text { OR }(95 \% \mathrm{Cl})\end{array}$ \\
\hline \multicolumn{5}{|c|}{ Occupational social class of household head * } \\
\hline Upper & 1.0 & 1.0 & 1.0 & 1.0 \\
\hline Middle-high & $1.4(1.0-1.9)$ & $1.3(1.0-1.8)$ & $1.2(0.9-1.7)$ & $1.1(0.8-1.6)$ \\
\hline Middle-middle & $2.3(1.7-3.0)$ & $2.1(1.5-2.8)$ & $1.8(1.3-2.4)$ & $1.5(1.1-2.0)$ \\
\hline Middle-low & $3.1(2.5-4.0)$ & $2.6(2.0-3.3)$ & $2.0(1.5-2.6)$ & $1.6(1.2-2.1)$ \\
\hline Lower-high & $3.7(3.0-4.5)$ & $3.0(2.5-3.8)$ & $2.1(1.7-2.7)$ & $1.6(1.3-2.0)$ \\
\hline Lower-low & $6.3(5.1-7.7)$ & $5.0(4.1-6.2)$ & $2.8(2.2-3.6)$ & $2.0(1.5-2.5)$ \\
\hline \multicolumn{5}{|c|}{ Occupational social class of first job ** } \\
\hline Upper & 1.0 & 1.0 & 1.0 & 1.0 \\
\hline Middle-high & $2.6(1.5-4.9)$ & $2.5(1.5-4.7)$ & $2.4(1.3-4.7)$ & $1.7(0.9-3.4)$ \\
\hline Middle-middle & $3.4(1.8-6.7)$ & $2.9(1.5-5.8)$ & $2.8(1.4-5.9)$ & $1.8(0.9-3.9)$ \\
\hline Middle-low & $5.2(3.1-9.5)$ & $4.6(2.7-8.3)$ & $4.0(2.3-7.6)$ & $2.2(1.2-4.2)$ \\
\hline Lower-high & $8.5(5.2-15.2)$ & $6.8(4.1-12.2)$ & $5.6(3.2-10.5)$ & $2.6(1.5-4.9)$ \\
\hline Lower-low & $20.0(12.2-35.9)$ & $15.2(9.2-27.3)$ & $10.4(6.0-19.7)$ & $4.1(2.3-7.9)$ \\
\hline \multicolumn{5}{|c|}{ Current occupational social class *** } \\
\hline Upper & 1.0 & 1.0 & 1.0 & 1.0 \\
\hline Middle-high & $2.1(1.4-3.1)$ & $2.2(1.5-3.2)$ & $2.0(1.3-2.9)$ & $1.9(1.2-2.8)$ \\
\hline Middle-middle & $4.3(3.5-5.4)$ & $4.1(3.3-5.2)$ & $3.2(2.5-4.2)$ & $2.8(2.2-3.6)$ \\
\hline Middle-low & $6.3(5.1-7.9)$ & $5.8(4.6-7.2)$ & $4.2(3.3-5.4)$ & $3.6(2.8-4.6)$ \\
\hline Lower-high & $6.8(5.4-8.6)$ & $5.8(4.6-7.5)$ & $4.4(3.3-5.7)$ & $3.7(2.8-4.9)$ \\
\hline Lower-low & $15.4(12.6-18.9)$ & $12.6(10.2-15.7)$ & $7.6(6.0-9.8)$ & $6.3(4.9-8.1)$ \\
\hline
\end{tabular}

95\% Cl: 95\% confidence interval; OR: odds ratio.

* Model 1: adjusted for gender, age, retired/active status, and race; Model 2: Model 1 + occupational social class of first job; Model 3: Model 2 + current occupational social class;

** Model 1: adjusted for gender, age, retired/active status, and race; Model 2: Model 1 + occupational social class of household head; Model 3: Model 2 + current occupational social class;

*** Model 1: adjusted for gender, age, retired/active status, and race; Model 2: Model 1 + occupational social class of first job; Model 3: Model $2+$ occupational social class of household head.

\section{Discussion}

The results from this study support the notion that SSS in adulthood results from a complex developmental process of socioeconomic self-perception, and includes current and past, individual and family experiences. In this study, low objective SEP indicators in childhood and adolescence remained associated with low SSS in adulthood, even after adjusting for current objective SEP indicators, which are the strongest associations. These findings support the hypothesis that SSS represents a cognitive average of SEP indicators across current and past experiences, as advocated by Singh-Manoux et al. 15 in their averaging hypothesis. Our results indicate that the associations between low SEP and low SSS are stronger for adulthood than for adolescence indicators. Similarly, our results also suggest that the associations between low SSS in adult life and low objective SEP indicators across the life-course tend to be stronger for self/individual than intergenerational indicators.

Analysis of objective socioeconomic trajectories suggests that upward mobility does not necessarily improve SSS in adulthood, as individuals exposed to adverse SEP as children or adolescents had lower SSS as adults than those who had better SEP in their childhood and adolescence. These results are in line with developmental psychology, which argues that the self-perception intrinsic to SSS is a 
Table 3

Association between low subjective social status (SSS) in society and nature of occupation of participant and household head at the time the participant started working. ELSA-Brasil, 2008-2010 ( $N=15,105)$.

\begin{tabular}{|c|c|c|c|c|}
\hline Variable & $\begin{array}{c}\text { Crude } \\
\text { OR }(95 \% \mathrm{Cl})\end{array}$ & $\begin{array}{c}\text { Model } 1 \\
\text { OR }(95 \% \mathrm{Cl}) \\
\end{array}$ & $\begin{array}{c}\text { Model } 2 \\
\text { OR }(95 \% \mathrm{Cl})\end{array}$ & $\begin{array}{c}\text { Model } 3 \\
\text { OR }(95 \% \mathrm{Cl})\end{array}$ \\
\hline \multicolumn{5}{|c|}{ Nature of occupation of household head * } \\
\hline Non-routine non-manual & 1.0 & 1.0 & 1.0 & 1.0 \\
\hline Routine non-manual & $3.3(2.8-4.0)$ & $2.9(2.5-3.5)$ & $2.5(2.1-3.0)$ & $1.9(1.6-2.4)$ \\
\hline Non-routine manual & $2.9(2.4-3.5)$ & $2.4(1.9-2.9)$ & $1.8(1.4-2.2)$ & $1.5(1.2-1.8)$ \\
\hline Routine manual & $4.3(3.6-5.1)$ & $3.3(2.8-4.0)$ & $2.2(1.8-2.7)$ & $1.7(1.4-2.1)$ \\
\hline \multicolumn{5}{|c|}{ Nature of occupation in first job ** } \\
\hline Non-routine non-manual & 1.0 & 1.0 & 1.0 & 1.0 \\
\hline Routine non-manual & $4.0(3.1-5.2)$ & $3.3(2.6-4.3)$ & $2.8(2.2-3.7)$ & $2.0(1.5-2.7)$ \\
\hline Non-routine manual & $7.4(5.6-9.7)$ & $5.3(4.0-7.1)$ & $4.4(3.3-5.9)$ & $2.7(2.0-3.6)$ \\
\hline Routine manual & $8.5(6.6-11.1)$ & $6.6(5.1-8.6)$ & $5.2(4.0-6.9)$ & $2.9(2.2-3.9)$ \\
\hline \multicolumn{5}{|c|}{ Current nature of occupation $* * \star$} \\
\hline Non-routine non-manual & 1.0 & 1.0 & 1.0 & 1.0 \\
\hline Routine non-manual & $2.9(2.5-3.3)$ & $2.6(2.2-3.0)$ & $2.1(1.8-2.4)$ & $1.9(1.6-2.2)$ \\
\hline Non-routine manual & $5.0(3.4-7.1)$ & $4.0(2.7-5.7)$ & $2.9(2.0-4.3)$ & $2.7(1.8-4.0)$ \\
\hline Routine manual & $7.8(6.8-9.0)$ & $6.3(5.5-7.3)$ & $4.4(3.8-5.2)$ & $3.9(3.3-4.6)$ \\
\hline
\end{tabular}

95\% Cl: 95\% confidence interval; OR: odds ratio.

* Model 1: adjusted for gender, age, retired/active status, and race; Model 2: Model 1 + nature of occupation in first job; Model 3: Model 2 + current nature of occupation;

** Model 1: adjusted for gender, age, retired/active status, and race; Model 2: Model 1 + nature of occupation of household head; Model 3: Model 2 + current nature of occupation;

*** Model 1: adjusted for gender, age, retired/active status, and race; Model 2: Model $1+$ nature of occupation in first job; Model 3: Model $2+$ nature of occupation of household head.

Table 4

Association between low subjective social status (SSS) in society and education of participant and mother. ELSA-Brasil, 2008-2010 ( $N=15.105)$.

\begin{tabular}{|c|c|c|c|}
\hline Variable & $\begin{array}{c}\text { Crude } \\
\text { OR }(95 \% \mathrm{Cl})\end{array}$ & $\begin{array}{c}\text { Model } 1 \\
\text { OR }(95 \% \mathrm{Cl})\end{array}$ & $\begin{array}{c}\text { Model } 2 \\
\text { OR }(95 \% \mathrm{Cl})\end{array}$ \\
\hline \multicolumn{4}{|l|}{ Maternal education } \\
\hline Tertiary & 1.0 & 1.0 & 1.0 \\
\hline Secondary & $1.5(1.0-2.4)$ & $1.5(1.0-2.3)$ & $1.2(0.8-1.8)$ \\
\hline Primary & $2.6(1.8-4.0)$ & $2.4(1.6-3.6)$ & $1.4(0.9-2.2)$ \\
\hline Incomplete primary & $4.4(3.0-6.6)$ & $3.8(2.6-5.7)$ & $1.8(1.2-2.8)$ \\
\hline No education & $9.0(6.2-13.6)$ & $7.3(5.0-11.2)$ & $2.3(1.5-3.6)$ \\
\hline \multicolumn{4}{|l|}{ Current education } \\
\hline Tertiary & 1.0 & 1.0 & 1.0 \\
\hline Secondary & $5.2(4.6-6.1)$ & $4.6(4.0-5.4)$ & $3.9(3.4-4.6)$ \\
\hline Primary & $8.4(6.9-10.1)$ & $7.5(6.2-9.2)$ & $6.0(4.9-7.5)$ \\
\hline Incomplete primary & $15.3(12.8-18.5)$ & $14.3(11.7-17.4)$ & $10.9(8.8-13.6)$ \\
\hline
\end{tabular}

95\%Cl: 95\% confidence interval; OR: odds ratio.

Model 1: adjusted for gender, age, retired/active status, and race; Model 2: Model 1 + current education. 
higher psychological function 21,22 that emerges in the early stages of life (termed by psychoanalysts as the mirror stage) concurrently to the development of language and thought 16 . In other words, we can postulate that individuals who have been exposed to adverse SEP in childhood and adolescence internalize and incorporate their family's household socio-cultural and historical contexts, expressing them in their adulthood SSS.

In the developmental process, the relationships between organisms and environments are mediated by socio-cultural and historical contexts 21,22 . Accordingly, the family/household context is one of the most important and early socio-cultural environment with which individuals interact 23 . Thus, SSS experiences probably develop under the influence of the family/household socio-cultural context in childhood, and continue to develop and accumulate new experiences into adolescence and adult life. In the current study, the use of SEP indicators based on maternal education and occupational social class of the household head aimed at estimating the contribution of the early contexts to the construction of adult SSS.

Less educated mothers, especially those without formal education, usually tend to have a more restricted and simpler worldview (that is, socio-cultural and historical symbolic systems) than more educated mothers. Thus, adults who had less educated mothers in childhood tend to have low SSS in adult life, because they continue, consciously or not, to be influenced by values, behaviors, habits and knowledge learned from their mothers during childhood. Similarly, household heads who have more routine manual occupations are expected to be more skilled in dealing with material tools than with signs compared to those in non-routine non-manual occupations, especially those involving greater cognitive demand. As adolescents are also subordinate and dependent on the socio-cultural and historical worldviews of the household head (although to a lesser degree than children), those from lowSEP households are also more likely to relate to more routine manual occupations. Finally, household heads from lower socio-occupational classes may be expected to have less resources and access to services and information than those from higher classes. Thus, once more, adolescents from the lower classes probably internalize and incorporate behaviors, values and habits of the socio-occupational class of the household head, impacting on their SSS as adults.

This may explain why the associations between low SSS in adult life and low objective SEP indicators across the life-course tended to be stronger for self/individual than intergenerational indicators: as the autonomy of a person increases with time, the influence of, and dependence on, the family or household of origin decreases, with a consequent increase of the free will of SSS in adult life. Moreover, it may also explain why the participants' occupational social class and nature of occupation in first job showed stronger associations with SSS than the contemporary household head indicators, and indicates that the former represents the individuals' own experiences more strongly.

The results presented herein should consider a few limitations. Measures such as maternal education are subject to memory bias and may even have changed over time. Paternal indicators in childhood such as paternal education were not measured or investigated, even though they likely contribute to current SSS. Due to SSS to be a complex sociological construct, measurement errors may have occurred in this study. Finally, the dichotomy in the response variable (low SSS versus the remaining six rungs in the 10-rung ladder representing SSS) may have resulted in information loss.

SSS, as opposed to most objective indicators, requires that individuals compare themselves to their counterparts in society 24 . This may add a new dimension to this indicator, not captured by objective indicators of SEP, incorporating the experiences of self in the societal context where the participant lives. This may be one of the explanations for differences in the associations of SSS and of objective SEP with regards to health outcomes. However, exploring this hypothesis is beyond the objectives of the current study.

Social stressors that last a long time are more likely to leave their imprint on the body under the form of disease and/or health behaviors 7. Results from a wide range of studies show that the biological consequences of exposure to psychosocial adversities are not transitory, but are cumulative. The normal functioning of the cardiovascular, immune, metabolic and nervous systems are disrupted. The finding that SSS in adulthood, a single and simple measure, conveys the long-term exposure to social adversities within and between generations, suggesting that SSS is good not only to assess health inequalities, but that it might also help to evaluate the subjective impact of social policies aimed at reducing socio-economic disparities. One could ask whether cash transfer programs such as Bolsa 
Família in Brazil change SSS. To investigate this dimension is not academic, it helps to estimate the extent to which such policies can alleviate the burden of social stressors on health in the short and long terms.

\section{Conclusions}

In conclusion, these findings indicate that SSS in adult life, as measured by the MacArthur Scale, captures social status in a longitudinal manner, integrating past and current experiences. In addition, the results suggest that the SSS of an adult includes influences from the family and household environment, which tend to affect SSS in adult life, even in the event of upward mobility. Thus, this study highlights the significance and originality of the contribution of SSS to studies on social inequalities in health and invites us to question the validity of adjusting associations between SSS and health conditions as objective SEP indicators. Future empirical research with longitudinal data may help to determine to what extent adulthood SSS is reversible and modifiable over time and the degree of influence that future prospects and achievements may impact current SSS.

\section{Contributors}

W. A. Ferreira, L. Giatti and S. M. Barreto contributed to design work, data analysis and interpretation and the writing of the manuscript. L. Camelo and M. C. Viana contributed to data analysis and interpretation and the critical review of the manuscript. All authors have approved the final version of the manuscript.

\section{Acknowledgments}

The ELSA-Brasil baseline study was supported by the Brazilian Ministry of Health (Science and Technology Department) and the Brazilian Ministry of Science and Technology (Funding Authority for Studies and Projects and Brazilian National Research Council - CNPq). S. M. B. and L. G. are research fellows of CNPq. S. M. B. is also a research fellow of Fminas Gerais State Research Foundation (FAPEMIG).

\section{References}

1. Chen B, Covinsky KE, Cenzer IS, Adler N, Williams BA. Subjective social status and functional decline in older adults. J Gen Intern Med 2012; 27:693-9.

2. Demakakos P, Nazroo J, Breeze E, Marmot M. Socioeconomic status and health: the role of subjective social status. Soc Sci Med 2008; 67:330-40.

3. Coher S, Alper CM, Doyle WJ, Adler N, Treanor JJ, Turner RB. Objective and subjective socioeconomic status and susceptibility to the common cold. Health Psychol 2008; 27:268-74.

4. Gong F, Xu J, Takeuchi DT. Beyond conventional socioeconomic status: examining subjective and objective social status with self-reported health among Asian immigrants. J Behav Med 2012; 34:407-19. 
5. Krieger N, Williams D, Moss N. Measuring social class in US public health research: concepts, methodologies and guidelines. Annu Rev Public Health 1997; 18:341-78.

6. Weber M. Ensaios de sociologia. Rio de Janeiro: LTC; 1982.

7. Adler NE, Stewart J. The MacArthur scale of subjective social status. http://www.macses. ucsf.edu/research/psychosocial/subjective.php (accessed on 04/Jun/2014).

8. Jackman MR, Jackman RW. An interpretation of the relation between objective and subjective social status. Am Sociol Rev 1973; 38:569-82.

9. Giatti L, Camelo LV, Rodrigues JFC, Barreto SM. Reliability of the MacArthur scale of subjective social status: Brazilian Longitudinal Study of Adult Health (ELSA-Brasil). BMC Public Health 2012; 12:1096.

10. Operario D, Adler NE, Williams DR. Subjective social status: reliability and predictive utility for global health. Psychol Health 2014; 19:23746.

11. Cundiff JM, Smith TW, Uchino BN, Berg CA. Subjective social status: construct validity and associations with psychosocial vulnerability and self-rated health. Int J Behav Med 2013; 20:148-58.

12. Krieger N. Epidemiology and the people's health: theory and context. Oxford: Oxford University Press; 2011.

13. Euteneuer F. Subjective social status and health. Curr Opin Psychiatry 2014; 27:337-43.

14. Miyakawa M, Magnusson HLL, Theorell T, Westerlund H. Subjective social status: its determinants and association with health in the Swedish working population (the SLOSH study). Eur J Public Health 2012; 22:593-7.

15. Singh-Manoux A, Marmot MG, Adler NE. Does subjective social status predict health and change in health status better than objective status? Psychosom Med 2005; 67:855-61.
16. Papalia DE, Olds SW, Feldman RD. Desenvolvimento humano. 8a Ed. Porto Alegre: Editora Artmed; 2006.

17. Corak M. Do poor children become poor adults? Lessons from a cross-country comparison of generational earnings mobility. Res Econ Inequal 2006; 13:143-88.

18. Adler N, Singh-Manoux A, Schwartz J, Stewart J, Matthews K, Marmot MG. Social status and health: a comparison of British civil servants in Whitehall-II with European- and AfricanAmericans in CARDIA. Soc Sci Med 2008; 66:1034-45.

19. Aquino EM, Barreto SM, Bensenor IM, Carvalho MS, Chor D, Duncan BB, et al. Brazilian Longitudinal Study of Adult Health (ELSABrasil): objectives and design. Am J Epidemiol 2012; 175:315-24.

20. Schmidt MI, Duncan BB, Mill JG, Lotufo PA, Chor D, Barreto SM, et al. Cohort profile: Longitudinal Study of Adult Health (ELSA-Brasil). Int J Epidemiol 2015; 44:68-75.

21. Vygotsky LS. A formação social da mente. São Paulo: Editora Martins Fontes; 1998.

22. Vygotsky LS. Pensamento e linguagem. São Paulo: Martins Fontes; 2008.

23. Engels F. A origem da família, da propriedade privada e do Estado. Rio de Janeiro: Civilização Brasileira; 1984.

24. Präg P, Mills MC, Wittek R. Subjective socioeconomic status and health in cross-national comparison. Soc Sci Med 2016; 149:84-92. 


\section{Resumo}

Pouco se sabe sobre a associação entre indicadores de posição socioeconômica na infância e adolescência e baixo status social subjetivo na idade adulta, depois de ajustar para posição socioeconômica na idade adulta. Usamos dados de linha de base (2008-2010) do Estudo Longitudinal de Saúde do Adulto (ELSA-Brasil), um estudo de coorte multicêntrico de 15.105 servidores públicos de seis estados brasileiros. O status social subjetivo foi medido com a Escala de MacArthur do Status Social Subjetivo, que representa a hierarquia social como uma escada de 10 degraus, onde o degrau mais alto representa o status social subjetivo mais alto. Os participantes que escolheram os quatro degraus inferiores foram alocados à categoria de status social subjetivo baixo. Foram investigados os seguintes indicadores de posição socioeconômica: infância (escolaridade materna), adolescência (classe social ocupacional do chefe de família; classe social ocupacional do participante no primeiro emprego; natureza da ocupação do chefe de família; natureza da ocupação do participante no primeiro emprego) e vida adulta (classe social ocupacional, natureza da ocupação e escolaridade do participante). A regressão logística múltipla foi usada para estimar as associações entre status social subjetivo baixo e posição socioeconômica, depois de ajustar para fatores sociodemográficos e indicadores de posição socioeconômica em outras fases da vida. Depois dos ajustes, os indicadores de posição socioeconômica baixa na infância, adolescência e idade adulta permaneceram associados significativamente com status social subjetivo baixo na idade adulta, com gradientes dose-resposta. A magnitude dessas associações foi maior para a posição socioeconômica intra-indivíduo do que para a posição socioeconômica intergeracional. Os achados indicam que o status social subjetivo na idade adulta resulta de um processo complexo de desenvolvimento da auto-percepção socioeconômica, intrínseco ao status social subjetivo e que inclui experiências atuais e passadas, individuais e familiares.

Classe Social; Fatores Socioeconômicos; Saúde do Adulto; Estudos de Coortes

\section{Resumen}

Se sabe muy poco sobre la asociación entre los indicadores objetivos de la posición socioeconómica durante la infancia y adolescencia y el bajo estatus social subjetivo en la etapa adulta, después de ajustar por la posición socioeconómica para adultos. Se usaron datos de la línea de base (2008-2010) del Estudio Longitudinal de Salud en Adultos (ELSA-Brasil), un estudio de cohorte multicéntrico con 15.105 empleados públicos, procedentes de seis estados brasileños. El estatus social subjetivo se midió usando la Escala de MacArthur del Estatus Social Subjetivo, que representa la jerarquía social como una escalera con 10 peldaños, donde el peldaño superior representa el estatus social subjetivo más alto. Los participantes que eligieron los cuatro escalones inferiores de la escalera fueron asignados a la categoría baja de estatus social subjetivo. Se investigaron los siguientes indicadores del contexto socioeconómico: infancia (educación materna), adolescencia (clase social ocupacional del cabeza de familia; la clase social ocupacional del primer trabajo de los participantes; naturaleza de la ocupación del cabeza de familia; naturaleza de la ocupación del primer trabajo de los participantes), y etapa adulta (clase social ocupacional de los participantes, naturaleza de la ocupación y educación). Las asociaciones entre un bajo estatus social subjetivo y el contexto socioeconómico se determinaron usando regresión múltiple logística, tras ajustarla para factores sociodemográficos e indicadores de la posición socioeconómica de otras fases de la vida. Tras los ajustes, un bajo contexto socioeconómico en la infancia, adolescencia y etapa adulta permaneció significativamente asociado con un bajo estatus social subjetivo en la etapa adulta con gradientes dosis-respuesta. La magnitud de estas asociaciones fue más fuerte para posición socioeconómico intra-individual que para el intergeneracional. Los resultados sugieren que el estatus social subjetivo en la etapa adulta es el resultado de un complejo proceso de desarrollo, donde se adquiere una autopercepción socioeconómica, que es intrínseca al estatus social subjetivo e incluye presente y pasado, así como experiencias individuales y familiares en el hogar.

Clase Social; Factores Socioeconómicos; Salud del Adulto; Estudios de Cohortes
Submitted on $15 / \mathrm{Feb} / 2017$

Final version resubmitted on 21/Sep/2017

Approved on 02/Oct/2017 